\title{
Pemberdayaan Usaha Maz Zakki Pada Badan Amil Zakat Nasional Kota Yogyakarta
}

\author{
Bandoko $^{1}$, A. Turmudzi ${ }^{2}$, MNK Al Amin ${ }^{3}$, \\ ${ }^{1}$ Kantor Wilayah Kementerian Agama Kantor DIY, ${ }^{2}$ UIN Walisongo, \\ ${ }^{3}$ Universitas Cokroaminoto Yogyakarta, . \\ *Penulis Koresponden, email: kholisnujib@gmail.com
}

\begin{abstract}
Abstrak
Program pemberdayaan ekonomi produktif dari Badan Amil Zakat Kota Yogyakarta (BAZKY) tahun 2017 adalah Maz Zakki yang berbeda dengan pelaksanaannya di tahun sebelumnya. Melalui penelitian kualitatif dengan pengumpulan data melalui wawancara mendalam, observasi dan dokumentasi bisa diketahui bahwa BAZKY telah memberikan bantuan dana zakat kepada warga yang tidak mampu berupa bantuan uang untuk usaha dengan pembinaan, pendampingan, dan pemantauan usaha. Hasil evaluasi menunjukkan proses pelaksanaan mulai dari persiapan, pelaksanaan dan pengawasan tetap mengikuti peraturan dan regulasi pengelolaan zakat nasional. Bahkan BAZKY melalui Mas Zakki telah memberikan pendampingan berkelanjutan berupa sekolah saudagar setelah menseleksi dengan kunjungan langsung ke rumah warga calon penerima bantuan dana usaha. Hal itu sekaligus bentuk pemantauan dan pengawasan dari keberlanjutan usaha. Pelaksanaan demikian telah memenuhi ketentuan dalam UUPZ berlaku di Indonesia sekarang. Hal itu tertuang dalam UndangUndang 23 tahun 2011 Tentang Pengelolaan Zakat. Di situlah aturan hukum tentang organisasi pengelola zakat setingkat BAZNAS maupun LAZ dijabarkan.
\end{abstract}

Kata Kunci: Zakat, Pemberdayaan usaha, Badan Amil Zakat, kemiskinan

\begin{abstract}
The productive economic empowerment program of the Badan Amal Zakat at Yogyakarta City (BAZKY) in 2017 is Maz Zakki which is different from its implementation in the previous year. Through qualitative research by collecting data through in-depth interviews, observation and documentation, it can be seen that BAZKY has provided zakat funds to poor citizens in the form of money for business with business coaching, mentoring, and monitoring. The results of the evaluation show that the implementation process, starting from preparation, implementation and supervision, still follows the national zakat management rules and regulations. Even BAZKY, through Mas Zakki, has provided ongoing assistance in the form of merchant schools after selecting them with direct visits to the homes of prospective recipients of business fund assistance. This is also a form of monitoring and supervision of business sustainability. Such implementation has met the provisions of the current Zakat Management Law in Indonesia. This is stated in Law 23 of 2011 concerning Management of Zakat. This is where the legal
\end{abstract}

This is an open access article under the (C-BY-SA license @) (1) (2) 
rules regarding zakat management organizations at the level of BAZNAS and LAZ are elaborated.

Keywords: zakat, economic empowerment, Badan Amil Zakat, poverty

\section{Pendahuluan}

Dalam Islam, pengurangan kemiskinan adalah persoalan bersama yang dilembagakan menjadi salah satu rukun Islam yang harus diamalkan oleh setiap muslim, yaitu zakat (Qadir 2001). Al-Zuhaily telah merangkum beberapa pengertian zakat meski tidak menyebut orang miskin secara langsung tetapi sebagai orang yang berhak menerimanya (Depag RI 2009). Mazhab Hanafi membatasinya pada, "Kadar tertentu dari harta tertentu pula sebagai hak milik yang sudah ditentukan karena Allah SWT." Pada mazhab Maliki dikenal sebagai, "Pengeluaran sebagian tertentu dari harta yang tertentu pula yang sudah mencapai batas jumlah yang diwajibkan zakat (nisab) kepada orang-orang berhak menerimanya manakala kepemilikan itu penuh dan sudah mencapai haul (setahun) selain barang tambang dan pertanian." Syafi'i kemudian mengkhususkan pada, "nama untuk kadar yang dikeluarkan dari harta atau benda dengan cara-cara tertentu." Pengikut mazhab Hanbali menjadikannya "hak dalam kadar tertentu yang diwajibkan untuk dikeluarkan dari harta tertentu untuk golongan tertentu pula dalam waktu tertentu pula." Zakat telah berbeda dengan wakaf meski sama-sama bagian dari kewajiban sedekah bagi pribadi muslim (Sukarno et al. 2019)

Catatan perlu diberikan bahwa zakat tidak sebatas menguntungkan bagi peningkatan kesejahhteraan kaum miskin tetapi juga berdampak positif terhadap para muzakki sebagai pelaksana zakat. Dalam etimologi bahasa Arab, zakat berasal dari kata "zaka". Artinya, berkah, tumbuh, bersih, suci, subur, dan baik, demikian penjelasan Ash-Shiddieqi (1976). Masuk didalam pengertiannya adalah penyuburan pahala dengan cara pengeluaran yang sedikit dari nilai nominal harta yang dimiliki diperuntukkan bagi orang-orang yang memerlukan sesuai ketentuan (Inoed et al. 2000). Makna lainnya ialah tumbuh dan bersih dimana tidak berlaku sebatas pada kekayaan, namun bisa diperuntukkan untuk kondisi kejiwaan pelaku zakat (Hasan 1995). Hal itu disebabkan karena zakat menjadi bagian dari upaya pensucian dan pembersihan diri dari tabiat kikir yang termasuk dosa (Muhammad 2006).

Di Indonesia, penghimpunan dana Zakat infak dan sodaqoh (ZIS) telah mengalami peningkatan drastik. Dalam Outlook Zakat Indonesia tahun 2017 tercantum penjelasan tentang perkembangannya mencapai 5310,15 persen selama 13 tahun (Pusat Kajian Strategis (Puskas) BAZNAS 2016). Di saat bencana nasional seperti tsunami aceh atau gempa bumi gunung Merapi bahkan terjadi kenaikan pengumpulan dana ZIS hingga kisaran 100 persen. apabila pertumbuhannya pertahun mencapai dirata-ratakan ditemukan 
sebesar 39,28 persen dari tahun 2002 sampai 2015.(Pusat Kajian Strategis (Puskas) BAZNAS 2016)

Perkembangan itu juga menjadi indikator dalam peningkatan kesadaran masyarakat yang tinggi untuk berzakat melalui organisasi pengelola zakat (OPZ), baik BAZNAS maupun LAZ. Selain itu, berbagai bentuk lembaga zakat seperti BAZ (Badan Amil Zakat) ataupun LAZ (Lembaga Amil Zakat) baik yang dikelola pemerintah maupun swasta di berbagai daerah di Indonesia juga telah bermunculan.

Pemerintah juga telah menunjukkan dukungannya melalui Undangundang Nomor 38 Tahun 1999 Tentang Pengelolaan Zakat. Perundangan itu kemudian telah direvisi dan disempurnakan sesuai perkembangan zakat di Indonesia dan internasional dalam Undang-undang nomor 23 Tahun 2011 tentang Pengelolaan Zakat (UUPZ) (Direktorat Pemberdayaan Zakat Kementerian Agama RI 2013). Di dalamnya telah disebutkan bahwa organisasi pengelolaan zakat terdiri dari Badan Amil Zakat (BAZ) dan Lembaga Amil Zakat (LAZ) yang dibentuk oleh masyarakat dan dikukuhkan dan dibina oleh Pemerintah. kekuatan undang-undang ini diharapkan mampu menjadi landasan penting pergerakan semua lembaga zakat sebagai lembaga sosial nirlaba yang yang berdampak pada kesejahteraan umat bahkan Negara Republik Indonesia (Fitriyah, Alim, dan Zuhdi 2008).

Faktor yang sangat berpengaruh kemudian adalah pengelolaan lembaga zakat itu sendiri. Mengingat dalam pengelolaan zakat bukan hanya penerimaan dan penyaluran zakat saja. Namun ada hal yang lebih penting dalam kaitannya dengan peningkatan perekonomian rakyat, yaitu bagaimana zakat diberdayakan sedemikian rupa, sehingga dapat menjadikan mustahik mampu menjadi muzakki. Peran intermediasi BAZ dan LAZ menjadi jelas dalam penghimpunan, pendistribusian dan pendayagunaan zakat (Fadillah, Lestari, dan Rosdiana 2017).

Puskaz Baznas (2016) telah menunjukkan zakat tidak sebatas menolong kesejahteraan mustahik. Dalam jangka panjang, pemberdayaan zakat bisa menjadi instrumen transformasi mereka menjadi muzakki. Hal demikian membktikan bahwa pemanfaatannya bisa mempengaruhi kondisi makro ekonomi negara, terutama kesenjangan ekonomi dan kemiskinan. Zakat telah berjasa sebagai penyeimbang pada bidang sektor ekonomi kesejahteraan nasional.

Biar dampak ekonomi zakat bisa berjalan secara berkelanjutan, maka sistem pendayagunaan zakat menjadi salah satu modal penting. Salah satu bentuknya telah diluncurkan oleh BAZKY berupa pemberdayaan ekonomi produktif para muzakki melalui zakat harta yang dihimpunnya sejak lama. Melalui Program Jogja Sejahtera, skema pemberdayaan usaha Mas Zakki menjadi satu upaya inovatifnya dari pemberdayaan tersebut sejak tahun 2017 (BAZNAS Kota Yogyakarta 2017a). 
Bentuk Maz Zakki sebagai pemberdayaan ekonomi produktif BAZKY menjadi berbeda dengan pelaksanaannya tahun sebelumnya. Untuk tahun 2016, BAZKY memberikan bantuan dana zakat kepada warga yang tidak mampu berupa bantuan uang untuk usaha tanpa pembinaan, pendampingan, dan pemantauan usaha. Hasil evaluasi menunujukkan akibatnya bagi dana zakat sebagai pengentas kemiskinan belum tercapai secara optimal. Maka untuk tahun 2017 ini mekanisme pemberian dana zakat yang disalurkan oleh BAZKY telah dilakukan pembenahan dari cara menseleksi, sebelumnya tidak ada kunjungan langsung ke rumah warga calon penerima bantuan dana usaha, saat ini ada. Dibuka sekolah saudagar sebagai wadah untuk pembinaan dan pendampingan bagi penerima bantuan dana zakat. Adanya pemantauan keberlanjutan usaha, jadi program BAZKY ini diharapkan akan benar-benar mengentaskan kemiskinan di kota Yogyakarta. Program dana zakat untuk usaha direncanakan akan diberikan setiap tahun (BAZNAS Kota Yogyakarta 2017a; Sujarweni 2016).

UUPZ yang berlaku di Indonesia sekarang adalah Ketentuan tentang pengelolaan zakat di Indonesia tertuang dalam Undang-Undang 23 tahun 2011. Di situlah aturan hukum tentang organisasi pengelola zakat setingkat BAZNAS maupun LAZ dijabarkan (Fadillah et al. 2017; Hakim 2016; Rianto, Junaidi, dan Setyawan 2016). Peratuannya mencakup; 1. Ketentuan Pengelolaan Zakat di Indonesia 2. Asas pengelolaan zakat 3. Tujuan pengelolaan zakat 4. Jenis-Jenis Zakat 5. Badan Amil Zakat Nasional (BAZNAS Pusat) 6. Badan Amil Zakat Nasional Provinsi dan Kota/Kabupaten 7. Lembaga Amil Zakat 8. Pengumpulan, Pendistribusian, Pendayagunaa dan Pelaporan Zakat 9. Pengelolaan Dana Infak, shadakah dan dana keaagamaan lainnya (DSKL) 10. Pembiayaan dalam pengelolaan zakat 11. Pembinaa dan pengawasan dalam pengelolaan zakat 12. Peran serta masyaraakat dalam pengelolaan zakat 13 . Sanksi administratif dan larangan dalam pengelolaan zakat (Republik Indonesia 2011).

\section{Metode}

Sifat penelitan kualitatif tentang pengelolaan zakat ini adalah deskriptif analitik sebagai prosedur pemecahan masalah yang diselidiki dengan menggambarkan atau melukiskan keadaan subyek atau obyek penelitian (Nawawi 2012:63). Dalam hal ini pengelola Badan Amil Zakat Kota Yogyakarta menjadi subyek penelitian, sedangkan sistem pendayagunaan zakat menjadi obyek penelitian. Data kemudian dikumpulkan dengan observasi, dokumentasi dan wawancara mendalam dengan informan yang berasal dari staf BAZKY. Data kemudian dianalisis dengan pendekatan sosioyuridis sehingga dapat diklasifikasikan dan kemudian dijelaskan kesesuaiannya dengan peraturan zakat di Indonesia. 


\section{Hasil dan Pembahasan}

Persiapan

Untuk menjamin kelancaran pelaksanaan pemberdayaan masyarakat melalui pemberian bantuan dana usaha berbentuk program Mas Zakky, BAZKY telah menetapkan Standar Operasional Prosedur (SOP). Didalamnya telah dijabarkan mengenai mekanisme pendayagunaan dana zakat dan sedekah mal termasuk program tersebut. Amil bahkan menguraikannya hingga jumlah mustahik dan jadwal dari kegiatan-kegiatan yang ada. Disitu telah diatur bahwa bantuan dana yang disalurkan sebanyak 80 (delapan puluh) mustahik. Pemberiannya diberikan dalam waktu tahunan pada bulan Maret dengan kewajiban bagi penerima untuk laporan perkembangan unit usaha dalam periode yang ditentukan. Sebagai aturan tambahan bahwa pengaturan lebih lanjut akan disusulkan dalam bentuk KAK/TOR(BAZNAS Kota Yogyakarta 2017b).

Dari sumber SOP, Para penerima dalam mas Zaky disyaratkan dari; Jamaah majelis taklim/ muallaf/ difabel/ ustadz/ jamaah kurang mampu wilayah Kota Yogyakarta dan bersedia aktif dalam pembinaan. Mustahik juga telah memiliki kelayakan dalam keterampilan maupun usaha berkembang. Mereka juga menyatakan bersedia didampingi tenaga ahli dari BAZNAS (BAZNAS Kota Yogyakarta 2017b).

Awal kegiatan dilakukan adalah sosialisasi. BAZKY melakukannya melalui berbagai sarana dan media sosial. Untuk sosialisasi lapangan dilakukan melalui majelis taklim, panti asuhan, dan takmir masjid. Sosialisasi tatap muka tampak menjadi penting. Bagi lembaga public seperti BAZKY memang cara demikian efektif. Pola demikian tidak menjadikan jarak antara lembaga dan pengguna dalam pelayanan public (Supratman et al. 2019). Media sosial yang digunakan yaitu dengan menyebarkan informasi melalui media social. Poster yang dapat tersebar dengan cepat kepada masyarakat ataupun brosur. Masyarakat dan lembaga keagamaan juga dilibatkan untuk meningkatkan pemahaman para mustahik agar tertarik mengikuti pemberdayaan bantuan Mas Zakki

Para mustahik mendaftar langsung datang ke Baznas dengan menyampaikan persyaratan penerima bantuan usaha. Syarat-syart itu adalah Kartu Tanda Penduduk (KTP), Kartu Keluarga (KK), Kartu Menuju Sejahtera (KMS), Surat Keterangan Tidak Mampu (SKTM). Semua itu perlu dilengkapi dengan surat rekomendasi dari majlis taklim dalam keaktifan keagamaan di lingkungan social sekitar tempat tinggal.

Surat rekomendasi majelis taklim merupakan salah satu bentuk ajakan BAZKY untuk pemberdayaan ekonomi sekaligus peningkatan spiritual. Hal itu dikarenakan untuk mendapatkan surat rekomendasi, mereka perlu mengikuti pengajian-pengajian yang ada di lingkungan dan masjid terdekat. Sebagian dari para mustahik merupakan orang-orang yang aktif dalam 
pengajian majelis taklim, akan tetapi ada beberapa mustahik yang belum aktif dalam pengajian, walaupun pada niat awal mengikuti pengajian hanya untuk mendapatkan surat rekomendasi, namun BAZKY sangat berharap dengan metode seperti ini akan membiasakan masyarakat untuk meningakatkan spiritualnya, salah satunya yaitu dengan mengikuti pengajian.

Setelah pengumpulan persyaratan tersebut, lalu dilakukan seleksi administratif. Sesuai SOP sebagai perwujudan terapan dari RKAT BAZKY Tahun 2017. penerima dana zakat produktif melalui mas Zakki diutamakan kepada jamaah majelis taklim, muallaf, difabel, ustadz, jamaah yang kurang mampu atau dengan kriteria fakir miskin untuk warga yang tinggal di wilayah Kota Yogyakarta. Sehingga BAZKY hanya menyalurkan untuk masyarakat dengan KTP Kota Yogyakarta saja.

Setelah itu BAZKY melakukan tahap seleksi untuk memilah mana yang patut untuk mendapatkan bantuan dana zakat dengan melihat langsung kondisi calon mustahik samapi ke tempat tinggal dan lingkungan kerjanya. jumlah tanggungannya, dan lokasi untuk calon usahanya juga dikunjungi. Dengan dilakukannya survei lapangan, badan amil juga dapat mempertimbangkan mengenai kesungguhan mustahik untuk menjalankan sebuah usaha melalui beberapa pertanyaan yang diajukan.

Mustahik yang layak terlibat dalam permberdayaan Mas Zakki kemudian dihubungi melalui sms ataupun telepon. Kontak itu untuk memberikan konfirmasi bahwa mereka terpilih dan berhak mendapatkan bantuan dana zakat.

Keberhasilan persiapan pelaksanaan pemberdayaan bantuan usaha Mas Zakki kemudian bisa dilihat dari intensitas sosialisasinya. Sosialisasi yang dilaksanakan pada dasarnya berdampak tidak semata Mas Zakki tetapi kepercayaan kepada BAZKY sebagai pengelola zakat di Kota Yogyakarta. Sri Fadillah telah meyakinkan bahwa pemahaman yang baik pada OPZ kepada masyarakat diharapkan dapat menjadi media informasi akan keberadaanOPZ baik BAZKY maupun LAZ yang pada akhirnya akan semakin banyak masyarakat yang mempercayakan donasi zakatnya pada OPZ (Fadillah et al. 2017).

UUPZ telah menjamin keberadaan BAZKY sebagai bagian dari OPZ. Zakat telah menjadi pranata sosial keagamaan dengan tujuan untuk pencapaian keadilan dan kesejahteraan bagi masyarakat. Untuk peningkatan daya dan hasil guna, zakat wajib dikelola secara kelembagaan dalam norma syariah (Republik Indonesia 2011). Aturan itu telah memberikan kepastian dan payung hokum bagi lembag amil BAZKY untuk mengatur mekanisme pengelolaan zakat sebagai berikut;

Pengelolaan zakat yang dilakukan oleh badan hokum organisasi termasuk BAZKY Kota berdampak pada keamanan dan kepercayaan. Kepentingan umat akan lebih terlindungi. Muzakki juga lebih mudah 
melaksanakan zakat dengan jaminan keamanan pada dana dijamin aman. Para mustahik pun merasakan manfaatnya tanpa kehilangan harga diri. Mereka lebih percaya diri dalam memperoleh bantuan zakat di lingkungan tempat tinggalnya. Pihak ketiga itu juga membatasi mereka yang tidak termasuk mustahik agar tidak bisa ikut menerima dana bantuan zakat.

Qardawi pun telah menjelaskan beberapa orang atau kelompok yang tidak boleh mendapat pembagian zakat (Qardawi 1991). Yaitu; Orang kaya yang mempunyai kelebihan harta, Orang kuat yang mampu bekerja, Orang yang tidak beragama dan orang fakir yang memerangi Islam, Anak-anak orang yang mengeluarkan zakat, kedua orang tua dan istrinya, dan Keluarga Nabi S.A.W yaitu Banu Hasyim saja, atau Banu Hasyim dan Banu Muthalib. Pelaksanaan

Setelah dipilih untuk berpartisipasi program Jogja Sejahtera melalui pemberdayaan usaha Maz Zakki, BAZKY Kota memberikan pelatihan kewirausahaan. Pelatihan dilakukan selama satu bulan dalam bentuk sekolah Saudagar. Frekwensi pertemuan sebanyak 4 kali pertemuan dalam satu bulan tersebut. Satu pertemuan terdapat 2 sesi. Mustahik terpilih wajib ikut.

Sujarweni (2016) menjelaskan lebih detil. Sekolah saudagar didirikan bertujuan memberikan pembinaan, pendampingan, pemantauan bagi penerima dana zakat, agar penerima dana dapat mengelola usahanya secara berkelanjutan. Penerima bantuan wajib bersekolah di sekolah saudagar dan lulus untuk mendapatkan sertifikat kelulusan sebagai bukti bahwa sudah siap untuk mulai usaha. Kemudian setelah lulus dari sekolah saudagar, gerobak beserta dana bantuan usaha diserah terimakan BAZKY ke masing-masing penerima dana disaksikan oleh camat masing-masing kecamatan. Penerima bantuan diwajibkan untuk menyisihkan uang keuntungannya sebesar 2,5\% perbulan untuk ditabung di bank yang sudah bekerjasama dengan BAZKY. Harapannya pengguliran dana zakat bisa jadi stimulan bagi kewirausahaan warga yang tidak mampu sehingga berdampak pada angka kemiskinan menurun di wilayah kota Yogyakarta.

Sekolah saudagar rencananya dibuka sepanjang tahun sebagai wadah pendidikan bagi calon pengusaha yang memperoleh dana zakat. Sekolah juga selalu memperbaiki kurikulum agar tercipta keberhasilan usaha dan mendukung pemerintah untuk mengentaskan kemuskinan di wilayah Yogyakarta. Sementara ini materi yang disampaikan adalah sebagai berikut; 1) Kewirausahaan angkringan, nara sumber pemilik angkringan, 2) Kewirausahaan gorengan, narasumber pemilik gorengan, 3) Kewirausahaan pulsa, narasumber pemilik gerai pulsa, 4) Pengelolaan laporan keuangan angkringan, 5) Pengelolaan laporan keuangan Gorengan, 6) Pengelolaan laporan keuamgan Pulsa, 7) Teknik pemasaran offline dan online, 8) Layanan kepuasan konsumen, 9) Pendampingan pengembangan usaha. Anjuran dapat diberikan untuk meluasakan wawasan strategis mereka dengan mengenalkan 
varian kerja sama usaha di Indonesia yang relevan dengan hokum Islam (Huda 2016)

Dengan demikian para mustahik belajar langsung mengenai bagaimana menjalankan sebuah usaha. dari manajemen keuangan, pemasaran, dan lainlain yang menunjang bagi pengembangan usaha yang sesuai dengan minatnya. Pelatihan ini diisi oleh para dosen Universitas Riau Yogyakarta. Para nara sumber lain yang sudah sukses dalam usaha-usaha mereka khususnya dalam 3 jenis usaha yang terkait yaitu angkringan, gorengan, dan pulsa juga dilibatkan.

Setelah pelatihan selama satu bulan, maka para mustahik mendapatkan sertifikat dari Sekolah Saudagar. Mereka pun kemudian mengikat kerja sama usaha dengan BAZKY Kota dalam Mas Zakki. Bentuknya adalah Perjanjian Hibah Terikat Zakat. Didalamnya ada ketentuan mustahik wajib untuk menabung sebesar 2,5\% dari hasil usaha dalam rekening tabungan atas nama mustahik yang sudah dibuatkan oleh pihak BAZKY kota melalui Bank daerah yang ada di DIY. Selain itu, para penerima dimotivasi untuk tetap partisipasi aktif dalam kegiatan keagamaan di masyarakat. Oleh karena itu BAZKY kota tidak hanya membantu para mustahik dalam aspek material atau finansial saja, tapi juga mengajak untuk meningkatkan aspek spiritual.

Pelaksanaan Mas Zakki memperjelas arti implementasi arti integrasi dalam pendayagunaan zakat. Gagasan besar penataan pengelolaan zakat di UUPZ yang menjiwai keseluruhan pasalnya adalah pengelolaan integratif. integrasi menjadi asas yang melandasi kegiatan pengelolaan zakat di Indonesia termasuk BAZKY. BAZNAS di semua tingkatan maupun LAZ yang mendapat legalitas setara sesuai kebutuhan. Menurut ketentuan undangundang, zakat yang terkumpul disalurkan berdasarkan prinsip pemerataan, keadilan dan kewilayahan.

Prinsip demikian menempatkan Integrasi pengelolaan zakat yang dilaksanakan oleh BAZKY sebagai koordinator. Peran koordinator merupakan satu kesenyawaan dengan integrasi. Pasal 6 dan 7 UUPZ dasar hukum yang memberikan ruang terbuka bagi fungsi koordinasi tersebut. Fuad Nasar menegaskan posisinya demkian secara hukum menjadi kuat, sehingga prinsip tuntunan syariah dalam Al Qur'an pada surat At-Taubah ayat 60 dapat terpenuhi (Nasar 2012).

Pengawasan

Pengawasan pada umumnya menjadi proses pengamatan dari pelaksanaan seluruh kegiatan untuk menjamin agar semua usaha yang sedang dilaksanakan berjalan dengan rencana yang ditetapkan. Didalalamnya termasuk proses untuk menerapkan pekerjaan apa yang sudah dilaksanakan, menilainya dan bila perlu mengoreksi, dengan maksud supaya pelaksanaan pekerjaan sesuai dengan rencana semula. Selama itu pengukuran dan 
perbaikan terhadap pelaksanaan kerja bawahan, agar rencana-rencana yang telah dibuat untuk mencapai tujuan-tujuan perusahaan dapat terselenggara. Demikian lah proses pengawasan berjalan.

Setelah proses serah terima bantuan usaha Mas Zaki mendapatkan gerobak beserta bantuan modal, mereka sudah mulai membuka usahanya di tempat yang sudah dipilih sebelumnya. Pendampingan dilakukan oleh pihak BAZKY dan Perguruan tinggi dengan cara mereka masuk dalam wadah sekolah saudagar kembali yang diselenggarakan setiap bulan. Pendampingan yang melibatkan banyak mitra termasuk perguruan tingi yang juga berpengalaman dalam pengabdian maupun pengembangan masyarakat bahkan peididikan pesantren (Musaropah 2016; Musaropah et al. 2019)

Pendampingan ini berupa pengecekan buku keuangan mereka dan buku tabungan mereka yang ada di bank. Serta diskusi pengalaman berjualan, keuntungan kerugian, Kendala yang dihadapi dan mencarikan solusi, serta materi yang paling penting adalah motivasi untuk tetap usaha di bidang usaha yang telah digeluti.

Bentuk pengawasan lainnya adalah ketentuan pelaporan keuangan bagi pengusaha Mas Zakki. Mereka didorong membuat pelaporan harian atau maksimal rekap laporan dalam seminggu. Laporan dapat langsung disampaikan melalui Whatsapp selain itu juga bisa diberikan melalui pendamping yang datang ke tempat usaha mustahik.

Dengan demikian pengawasan menjadi pokok dalam pelaksanaan pemberdayaan Mas Zakki. Bentuknya adalah pendampingan, bahkan pengawasan terlihat lebih jelas dibandingkan tahun-tahun sebelumnya. Pengawasan itu sudah dilakukan dari awal sebelum modal disalurkan yaitu dalam bentuk pelatihan yang sifatnya wajib. Pendampingan kondisional berupa pemantauan secara langsung ke lokasi oleh tim pendamping juga dilakukan. Pendampingan dengan koordinasi dan supervise laporan yang harus dilaporkan dalam bentuk harian atau mingguan melalui media sosial atau sms, sehingga perkembangan usaha setiap mustahik lebih terpantau dengan jelas. Dengan tujuan meningkatkan jiwa usaha, menabung, dan tanggung jawab para mustahik.

Bagi BAZKY dan stake holder yang terlibat, pengawasan demikian menjadi bahan penting evaluasi strategi pemberdayaan mustahik, khususnya dalam bantuan usaha Mas Zakki yang berjalan. Upaya itu dilakukan dengan mengukur tingkat keberhasilan yang dicapai guna untuk menetapkan tujuan berikutnya. Artinya, fungsinya menjadi tolok ukur untuk kegiatan selanjutnya. Karena sebuah strategi dapat dimodifikasi di masa depan perlu dasar berupa peristiwa perubahan dalam faktor internal maupun eksternal di saat berjalan.

Kegiatan pokok dalam evaluasi program antara lain adalah mengkaji atau meninjau ulang faktor-faktor eksternal maupun internal yang menjadi 
landasan perumusan strategi yang diterapkan sekarang. Dalam tahap evaluasi adalah proses untuk memastikan bahwa kegiatan dari perumusan strategi implementasi yang sudah berjalan sesuai dengan rencana yang ditentukan. Kegiatan yang dilakukan yaitu dengan mengevaluasi keberhasilan organisasi dalam pencapaian tujuan penyaluran, melakukan tindakan perbaikan atau koreksi apabila ada penyimpangan dalam pelaksanaan kegiatan, serta membuat konsep yang dapat menjadi solusi dari kekurangan yang sudah terjadi sebelumnya.

Tata kelola yang diterapkan oleh BAZKY dengan cara mengevaluasi dan mengubah konsep penyaluran dana zakat, serta memperkuat dari sisi pendampingan mustahik. Setiap evaluasi tahunan, lembaga selalu merancang konsep baru berdasarkan dari kekurangan-kekurangan dari konsep tahun sebelumnya. Sehingga adanya penyesuaian konsep dengan kinerja para mustahik terhadap modal usaha yang sudah diberikan. penyaluran dana zakat pada bidang pemeberdayaan ekonomi menjadi terus meningkat di setiap tahunnya. pengelolaanna pun dapat berjalan dengan efektif. Tata kelola yang tidak memiliki sistem monitoring atau evaluasi, maka akan sulit untuk berbernah dan berkembang untuk ke depannya.

Mekanisme yang dinamis diambil BAZKY dalam pengawasan dan evaluasi secara periodic bahkan saat berjalan sejak awal pelaksanaan Mas Zakki. Artinya, pengawasan demikian bisa memudahkan BAZKY Kota bisa mengetahui dimana letak kelemahan atau kekurangan dari implementasinya bagi kesejahteraan mustahik. Perubahan dan perkembangan yang terjadi merupakan hal yang wajar saja terjadi karena perubahan tersebut didasarkan pada hasil evaluasi yang berkelanjutan dan berdasar kenyataan.

Dengan pengawasan demikian BAZKY telah memberikan kepastian bagi konstruksi hukum yang tepat untuk optimalisasi penarikan dan penyaluran zakat kepada pihak-pihak yang menjadi obyek penerima zakat melalui Mas Zakki berdasar dinamika perjalanan usaha yang digeluti oleh penerima bantuan. Pendayagunaan zakat yang merupakan bentuk pemerataan pendapatan sehingga perlu dikelola dengan baik agar tidak menimbulkan ketergantungan dari pihak mustahik. Pemberdayaan kemudian bukanlah sekedar pola menengadahkan tangan ke atas untuk menerima dari pihak pemberi dan penerima mempergunakan untuk kepentingan konsumtif. Zakat yang diberikan haruslah berfungsi sebagai motivasi untuk meningkatkan taraf kehidupan lebih baik (Purbasari 2015).

Pengawasan demikian berpengaruh pada pencapaian tujuan dari pengelolaan Zakat. Hal itu telah diatur dalam pasal 3 UUPZ. Didalamnya telah dijelaskan bahwa tujuan dari pengelolaan zakat adalah Pertama, meningkatkan efektivitas dan efisiensi pelayanan dalam pengelolaan zakat. Kedua, meningkatkan manfaat zakat untuk mewujudkan kesejahteraan masyarakat dan penanggulangan kemiskinan. 


\section{Penutup}

Dengan melihat proses pengawasan yang melibatkan berbagai pihak, BAZKY kota seperti lembaga zakat lainnya. Lembaga itu termasuk dalam lembaga publik. Bahkan sumber pembiayaan yang berbentuk zakat, infak dan shadaqah yang dikelola juga berasal dari masyarakat (umat Islam) untuk masyarakat. Oleh karena itu, budaya organisasinya yang berjenjang dari mulai tingkat nasional dan daerah membuat aspek pengawasan adalah hal yang harus dilakukan di tiap level, dari yang tertinggi hingga yang terendah termasuk dalam program pemberdayaan. Pertanggungjawaban kegiatannya harus dilaporkan melalui unsur perwakilan masyarakat di pemerintah. Stakeholders-nya tidak dimiliki oleh individu dan kelompok secara khusus, tetapi seluruh umat Islam tidak dibatasi oleh lingkup wilayah tertentu. Pengawasan melekat dan berkelanjutan menjadi keharusan.

\section{Daftar Pustaka}

Ash-Shiddieqy, Hasbi. 1976. Beberapa Permasalahan Zakat. Jakarta: Tintamas.

BAZNAS Kota Yogyakarta. 2017a. Laporan Keuangan dan Laporan Auditor Independen Untuk Tahun Yang Berakhir 31 Desember 2017. Yogyakarta.

BAZNAS Kota Yogyakarta. 2017b. Standar Operasional Prosedur Pentasyarufan dan Pendayagunaan BAZNAS Kota Yogyakarta. Yogyakarta: BAZNAS Kota Yogyakarta.

Depag RI. 2009. Fiqh Zakat. Jakarta: Direktorat Pemberdayaan Zakat Direktorat Jenderal Bimbingan Masyarakat Islam.

Direktorat Pemberdayaan Zakat Kementerian Agama RI. 2013. Panduan Organisasi Pengelola Zakat. Jakarta: Dirjend Bimas Islam Direktorat Pemberdayaan Masyarakat.

Fadillah, Sri, Rini Lestari, dan Yuni Rosdiana. 2017. "Organisasi Pengelola Zakat (OPZ): Deskripsi Pengelolaan Zakat Dari Aspek Lembaga Zakat.” Kajian Akuntansi 18(2):148-63.

Fitriyah, M. Nizarul Alim, dan Rahmat Zuhdi. 2008. "Keuangan Organisasi Nirlaba (Study Kasus Pada Baitul Maal Hidayatullah Surabaya)." Jurnal Infestasi 4(1):75-94.

Hakim, Budi Rahmat. 2016. "Analisis Terhadap Undang-Undang Nomor 23 Tahun 2011 Tentang Pengelolaan Zakat (Perspektif Hukum Islam)." Syariah Jurnal Hukum dan Pemikiran 15(2):155-66. doi: 10.18592/syariah.v15i2.552.

Hasan, Sofyan. 1995. Pengantar Hukum Zakat dan Wakaf. Surabaya: Al-Ikhlas. Huda, Moh Shofiyul. 2016. "Kontrak Kerja Sama Usaha Di Indonesia Dalam Perspektif Hukum Islam." Realita: Jurnal Penelitian dan Kebudayaan Islam 14(2):135-47. doi: 10.30762/REALITA.V14I2.240.

Inoed, Amiruddin, Heri Junaidi, Suyitno, dan Adib Abdushomad. 2000. Anatomi Figh Zakat Potret dan Pemahaman Badan Amil Zakat Sumatra Selatan. Yogyakarta: Pustaka Pelajar.

Muhammad, Sahri. 2006. Mekanisme Zakat dan Permodalan Masyarakat Miskin. Malang: Bahtera Press.

Musaropah, Umi. 2016. "Pemberdayaan Masyarakat Dalam 
Penyelenggaraan Pendidikan Anak Usia Dini Berbasis Pesantren." AsSibyan: Jurnal Pendidikan Anak Usia Dini 1(2).

Musaropah, Umi, Suharto Suharto, Daluti Delimanugari, Agus Suprianto, Rubini Rubini, Retno Kurnianingsih, dan Citra Ayudiati. 2019. "Pengembangan Kewirausahaan Berbasis Industri Kreatif Bagi Jamaah Wanita Majelis Taklim Di Desa Kepek." Nuansa Akademik: Jurnal Pembangunan Masyarakat 4(2):79-90.

Nasar, M. Fuad. 2012. "Integrasi Pengelolaan Zakat dalam UU No. 23 Tahun 2011 | BAZSRAGEN." Diambil 14 Juni 2018 (https:// www.bazsragen.org/2012/11/integrasi-pengelolaan-zakat-dalam-uu-no23-tahun-2011/).

Nawawi, Hadari. 2012. Metode Penelitian Bidang Sosial. Yogyakarta: Gajah Mada University Press.

Purbasari, Indah. 2015. "Pengelolaan Zakat Oleh Badan Dan Lembaga Amil Zakat Di Surabaya Dan Gresik." Mimbar Hukum 27(1):68-81.

Pusat Kajian Strategis (Puskas) BAZNAS. 2016. Outlook Zakat Indonesia 2017. Jakarta: Puskas BAZNAS.

Qadir, Abdurrachman. 2001. Zakat dalam Dimensi Mahdah dan Sosial. Jakarta: RajaGrafindo Perkasa.

Qardawi, Yusuf. 1991. Fikih Zakat. Jakarta: Litera Antar Nusa.

Republik Indonesia. 2011. Undang-Undang RI Nomor 23 tahun 2011 tentang Pengelolaan Zakat.

Rianto, Agus, Junaidi, dan Ary Setyawan. 2016. "Pelaksanaan Pasal 27 Undang-Undang No. 23 Tahun 2011 Mengenai Zakat Produktif Di BAZNAS Kabupaten Karanganyar." Yustisia 5(2):415-34.

Sujarweni, V. Wiratna. 2016. "Sekolah Saudagar: Pemberdayaan Dana Zakat Untuk Usaha Dalam." Prosiding Seminar Nasional dan Call for Papers "Pengembangan Sumber Daya Perdesaan dan Kearifan Lokal Berkelanjutan VI" 24-25 November 2016 Purwokerto 8(November).

Sukarno, Sukarno, Supriyono Supriyono, Miftachul Alfin, Fattah Setiawan, Moh. Shofiyul Huda MF, dan Busyro Busyro. 2019. "Analisis Implementasi Wakaf Tanah di Kecamatan Pandak Kabupaten Bantul." Nuansa Akademik: Jurnal Pembangunan Masyarakat 4(2):133-44.

Supratman, Bawa, Fatah Nashir, A. S. Rahman, Zainul Arifin, dan Cipto Sembodo. 2019. "Pelaksanaan Jaring Aspirasi Sebagai Komunikasi Publik Pemerintah Daerah Kabupaten Kulon Progo." Nuansa Akademik Jurnal Pembangunan Masyarakat 4(1):1-16. 